\title{
DETERMINAN FAKTOR SOSIAL DAN EKONOMI TERHADAP KEMISKINAN PENDUDUK
}

\author{
Sirilius Seran \\ Fakultas Ekonomi Universitas Timor \\ Jalan Eltari Km.9, Kelurahan Sasi, Kecamatan Kota Kefamenanu, Timor \\ Nusa Tenggara Timur, Telepon/Fax: 0388(2433012) \\ E-mail: siriliusseran@yahoo.co.id
}

Diterima 8 Oktober 2011 / Disetujui 29 April 2012

\begin{abstract}
Increasing the quality of human resource via education investment is a sine qua non for welfare promotion as well as for poverty solution. Education, inflation, income per capita, consumption, regional gross domestic product, and economy growth are a number of variables that directly and indirectly affect the poverty. The research uses time series data of the last ten years (1999-2009) obtained from Central Agency on Statistics (BPS). The aim of this research is to identify the causal relationship of the influential variables mentioned. The path analysis is used to analyze the data based on the five models. The simultaneous testing of table summary shows that the Regression coefficient value of each model is significant, where $F$ value is smaller than alpha 0,05. The similar conclusion is also shown in partial testing between the independent variables and dependent variables.
\end{abstract}

Keywords: education, income, economy growth, path analysis, poverty

\begin{abstract}
Abstrak: Peningkatan sumberdaya manusia melalui investasi pendidikan merupakan syarat mutlak untuk meningkatkan kesejahteraan dan mengatasi kemiskinan penduduk. Beberapa variabel sosial dan ekonomi yang mempengaruhi secara langsung maupun tidak langsung terhadap kemiskinan adalah pendidikan, inflasi, pendapatan perkapita, konsumsi, Produk Domestik Regional Bruto, dan pertumbuhan ekonomi. Data yang digunakan adalah time series antara tahun 1999-2009 berasal dari Badan Pusat Statistik. Tujuan dari penelitian ini adalah untuk mengetahui hubungan sebab akibat (kausal) antara variabel penelitian. Alat analisis yang digunakan adalah analisis jalur (path analysis), berdasarkan lima macam model. Hasil analisis pengujian secara simultan menunjukkan bahwa nilai koefisien regresi $(R)$ untuk masing-masing model bersifat signifikan, nilai Signifikan F, lebih kecil dari alfa 0,05. Kesimpulan serupa juga berlaku bagi pengujian parsial, antara masing-masing variabel bebas dengan variabel tak bebas.
\end{abstract}

Kata kunci: pendidikan, pendapatan, pertumbuhan ekonomi, analisis jalur, kemiskinan

\section{PENDAHULUAN}

Pembentukan modal manusia melalui investasi dalam bidang pendidikan merupakan cara terbaik untuk meningkatkan pertumbuhan ekonomi. Schultz pada tahun 1978 menemukan bahwa di Kanada, kontribusi pendidikan terhadap pertumbuhan ekonomi sebesar 25 persen, di Ghana: 23,2 persen lebih besar dari yang terjadi di Amerika Seikat sebesar: 15,0 persen
(Suryadi, 1997). Angka ini tentu lebih kecil dari kontribusi yang berasal dari faktor teknologi dan faktor produksi lainnya, tetapi dalam jangka panjang peran pendidikan bagi pembangunan akan semakin besar seiring dengan makin pesatnya kemajuan ilmu pengetahuan dan teknologi. Hal inilah yang mengakibatkan pengeluaran pemerintah terutama di negaranegara maju terhadap investasi pendidikan cukup besar, setidaknya diamati dari rasio inves- 
tasi pendidikan terhadap GNP di Amerika Serikat mencapai 12,5 persen tidak jauh berbeda dengan rasio investasi fisik (Psacharopoulos, 1993).

Peningkatan kualitas tenaga kerja melalui investasi pendidikan mempunyai korelasi dengan pendapatan. Pendapatan dapat didefinisikan sebagai balas jasa yang diperoleh faktor produksi karena keterlibatannya dalam proses produksi. Secara konvensional dikenal 4 macam faktor produksi: tanah, tenaga kerja, modal, skill (entrepreneurship). Dua faktor produksi yang disebutkan pertama dikenal sebagai faktor produksi pokok, dianut oleh kelompok masyarakat tradisional. Kegiatan produksi dalam masyarakat tradisional hanya menggunakan faktor produksi tanah dan tenaga kerja. Jenis pendapatan yang diperoleh dari penyertaan tanah dalam kegiatan produksi disebut sewa tanah. Sedangkan pendapatan bagi tenaga kerja yang terlibat didalam kegiatan produksi disebut upah/gaji. Kecuali itu, pendapatan yang diperoleh karena kepemilikan faktor modal, skill dan teknologi masing-masing disebut sebagai bunga modal dan keuntungan (Mankiw, 2003). BPS (September 2010: 41) mencatat bahwa tenaga kerja Indonesia masih didominasi oleh penduduk yang berpendidikan SLTA ke bawah. Tahun 2008 dari 102,05 juta orang tenaga kerja terdapat 94 persen yang berpendidikan SLTA ke bawah, 6 persen lainnya tamat Perguruan Tinggi.

Kondisi ini telah berpengaruh terhadap besarnya pendapatan dan pertumbuhan ekonomi dan kemiskinan penduduk. Data yang disajikan oleh World Bank, Unesco, dan Dikti tahun 2011 (Materi Presentasi Direktur Kelembagaan Dikti RI, 2011) yang diplotkan dalam Garis regresi $(Y=3853,96+359,64 X)$ mengarah ke kanan atas menunjukkan bahwa lulusan Teknik, Sains dan Pertanian mempunyai hubungan positif dengan nilai PDRB perkapita, setidaknya berlaku bagi tiga Negara yang diamati adalah Malaysia, Portugal, dan Indonesia.

Besarnya pendapatan setiap faktor produksi sangat bervariasi, tergantung kepada tinggi/ rendahnya produktivitas. Produktivitas merupakan rasio antara input dengan output produksi, diukur dari banyaknya ouput yang dihasilkan yang tergantung kepada kualitas tenaga kerja. Sjamtjik, (2003) mengatakan bahwa, tingkat upah bervariasi antara pekerjaan yang satu dengan pekerjaan lainnya disebabkan oleh:

(1) Pekerjaan yang beragam (Heterogeneous Jobs). Beberapa hal di luar gaji (dalam bentuk uang) yang menyebabkan terjadinya perbedaan upah yang diterima tenaga kerja adalah: fasilitas kerja (Job Aminities), penerimaan tenaga kerja berdasarkan keterampilan (Skill Requirement), pembayaran upah yang efisien (Efficiency $W a-$ ges), pekerjaan sampingan (Other Job).

(2) Pekerja yang beragam (Heterogeneous Workers). Keragaman di antara para pekerja menyebabkan perbedaan upah dari masing-masing tenaga kerja itu sendiri. Keragaman pekerja ini didasarkan kepada perbedaan mutu modal manusia (Human Capital Differencies) dan keinginan pekerja (Worker Preferencies).

(3) Pasar kerja yang tidak sempurna. Adanya

Tabel 1. Penduduk Usia 15 Tahun ke Atas yang Bekerja Menurut Pendidikan Tertinggi yang ditamatkan Periode Februari 2008-2010 (juta orang)

\begin{tabular}{|c|c|c|c|}
\hline \multirow{2}{*}{$\begin{array}{l}\text { Pendidikan Tertinggi yang } \\
\text { ditamatkan }\end{array}$} & \multicolumn{3}{|c|}{ Tah un } \\
\hline & 2008 & 2009 & 2010 \\
\hline SD ke bawah & 55,62 & 55,43 & 55,31 \\
\hline Sekolah Menengah Pertama & 19,39 & 19,85 & 20,30 \\
\hline Sekolah Menengah Atas & 13,90 & 15,13 & 15,63 \\
\hline Sekolah Menengah Kejuruan & 6,71 & 7,19 & 8,34 \\
\hline Diploma (I/II/III) & 2,66 & 2,68 & 2,89 \\
\hline Universitas & 3,77 & 4,22 & 4,94 \\
\hline Jumlah & 102,05 & 104,49 & 107,41 \\
\hline
\end{tabular}

Sumber: BPS-Laporan Bulanan, Data Sosial Ekonomi Edisi 4 September 2010 
perbedaan antara permintaan (Demand) dan penawaran (Supply) tenaga kerja dalam pasar kerja telah memicu perbedaan pemberlakuan tingkat upah terhadap tenaga kerja. Bila jumlah tenaga yang ditawarkan lebih banyak dari yang dibutuhkan akan menurunkan tingkat upah (Cateris Paribus) tetapi sebaliknya bila jumlah tenaga kerja yang ditawarkan lebih sedikit dari yang dibutuhkan oleh pasar maka tingkat upah tenaga kerja akan mengalami kenaikan (Gambar 1).

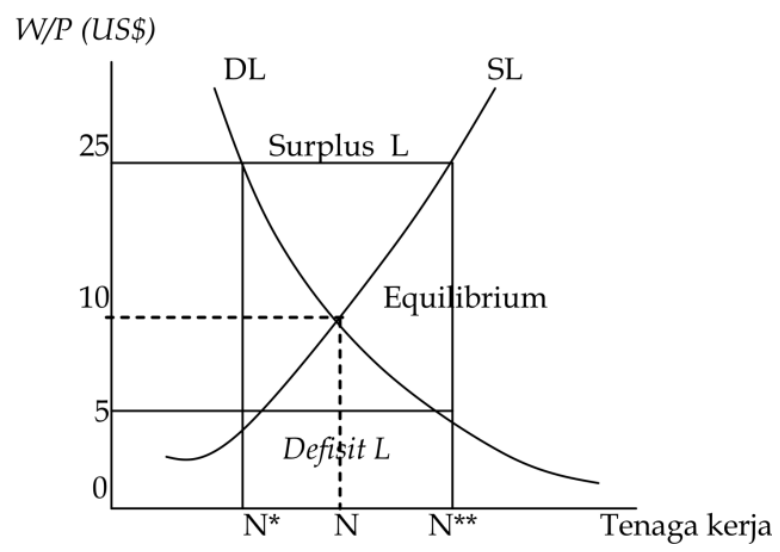

Gambar 1. Tingkat Upah di Pasar Tenaga Kerja

Upah (Wages) yang berlaku di pasar kerja merupakan harga daripada tenaga kerja yang bersangkutan. Penentuan tingkat upah sangat tergantung kepada kekuatan tarik menarik antara permintaan dan penawaran di pasar tenaga kerja. Pada tingkat upah sebesar US\$10 merupakan upah riil keseimbangan (equilibrium $=$ E) terjadi pada saat jumlah antara permintaan (demand labor) dan penawaran tenaga kerja (supply labor) adalah sama sebesar N (DL=SL). Semua tenaga kerja terserap, sehingga tidak ada pengangguran. Tetapi keadaan menjadi terbalik ketika tingkat upah yang berlaku lebih kecil atau lebih besar daripada upah keseimbangan (US\$10). Misalnya upah yang berlaku setinggi US\$25, (upah tertinggi) orang berbondong-bondong menawarkan tenaganya sebanyak $\left(\mathrm{N}^{* *}\right)$, padahal jumlah yang diminta hanya sebesar $\left(\mathrm{N}^{*}\right)$. Ini berarti terjadi kelebihan (surplus) tenaga kerja, tidak semua tenaga kerja tertampung di pasar kerja, sehingga menimbulkan pe- ngangguran. Hal serupa juga terjadi ketika tingkat upah yang berlaku dipasar lebih kecil dari tingkat upah keseimbangan (US\$10), misalnya upah menjadi (US\$5), merupakan upah terendah. Banyak orang akan memilih untuk menganggur daripada bekerja dengan menerima upah yang sangat rendah. Jenis pengangguran yang semacam ini dikategorikan sebagai pengangguran terpaksa.

Psacharopoulos pada tahun 1989 dalam penelitiannya di Venezuela menemukan bahwa rata-rata pendapatan yang diterima oleh tenaga kerja yang berpendidikan tinggi sebesar 178,297 Bolivares/tahun, lebih tinggi dari yang berpendidikan sekolah menengah: 106,337 Bolivares/ tahun sedangkan untuk yang tamat SD dan tidak tamat SD masing-masing pendapatannya sebesar: 69,452 dan 39,625 Bolivares/tahun (Psacharopoulos, 1995)

Biro Pusat Statitik Amerika (Bureau of the Census) pada tahun 1994 menyampaikan bahwa rata-rata penghasilan tenaga kerja di Amerika Serikat untuk yang berpendidikan Doktor mencapai US\$54.904.0000/tahun, jauh lebih tinggi dari tenaga kerja yang berpendidikan Magister, atau Sarjana. Rata-rata penghasilan terendah diterima oleh tenaga kerja yang berpendidikan tidak tamat SD sebesar: US\$ 12.809.000/tahun (Suryadi, 1997).

Mankiw pada tahun 2003 mengatakan pendapatan dapat digunakan untuk: (1) konsumsi, dan (2) tabungan. Besar atau kecilnya pembiayaan konsumsi rumah tangga tergantung kepada jumlah jiwa yang menjadi tanggungannya. Tanggungan di sini tidak hanya terbatas pada keluarga inti (nuclear family) melainkan juga termasuk anggota keluarga di luar rumah (extended family). Robins (1990) mengatakan bahwa besar tanggungan adalah banyaknya orang yang serumah yang menjadi tanggungan orang tua termasuk anak kandung, anak angkat kedua orang tua dan keluarga lainnya.

Backer (1993), dalam "A Treatise on the Family", mengatakan bahwa terdapat trade-off antara jumlah tanggungan (konsumsi) dengan kualitas anak dalam keluarga. Keluarga yang memiliki jumlah tanggungan (anggota keluarga) yang relatif kecil cenderung mempunyai kemampuan yang relatif lebih tinggi untuk 
membiayai pembentukan kualitas anak.

Secara teoritis kualitas anak-anaknya relatif lebih tinggi daripada keluarga yang memiliki jumlah tanggungan yang relatif besar. Backer (1993:147), selanjutnya menunjukkan hubungan keterkaitan tersebut dalam gambar indiffirence (Gambar 2).

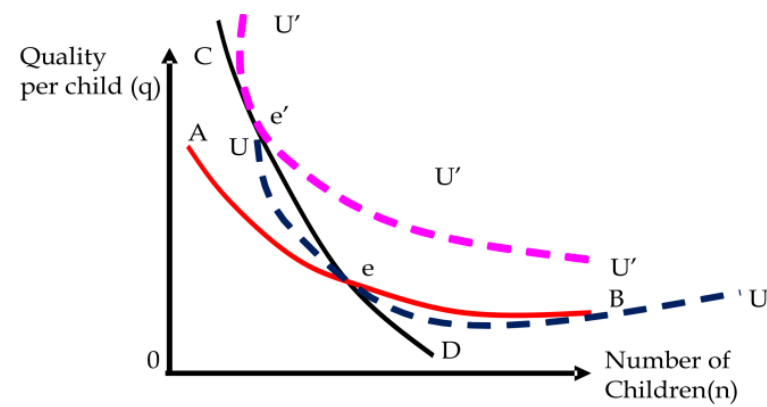

Sumber: Gary S. Backer (1993),

\section{Gambar 2. Hubungan Antara Kualitas Anak de- ngan Jumlah Anak}

Garis $\mathrm{AB}$ dan $\mathrm{CD}$ masing-masing sebagai garis anggaran (budget line) yang berbentuk cembung ke titik origin, sebagai akibat dari interaksi dalam menentukan pilihan antara jumlah barang $\mathrm{n}$ dan barang $\mathrm{q}$ yang dibutuhkan. Kepuasan maksimum terjadi pada persinggungan antara garis anggaran dan kurva indifference ( $U$ dan $\left.U^{\prime}\right)$. Titik e dan $e^{\prime}$ merupakan kepuasan maksimum yang dicapai orang tua dalam memenuhi kebutuhan atas 2 (dua) jenis barang tersebut. Artinya dengan tingkat pendapatan tertentu ( $A B$ dan $C D$ ) orang tua dapat membelanjakan untuk barang $\mathrm{n}$ dan barang $\mathrm{q}$, masing-masing mendapat titik kepuasan yang sama besarnya, terjadi pada titik e dan $\mathrm{e}^{\prime}$ tersebut. Dalam kasus tersebut, keluarga yang memiliki banyak tanggungan akan mempunyai kemampuan yang relatif terbatas untuk menyekolahkan anak-anaknya pada tingkat pendidikan yang lebih tinggi. Jangankan tabungan, konsumsi setiap harinya juga jauh dari ketentuan/standar kesehatan. Mereka hidup seadanya, makan/minum dan pakaian apa adanya. Banyaknya tanggungan telah dan akan mempersulit mereka untuk melakukan investasi untuk pendidikan anak-anaknya, sehingga beraki- bat negatif terhadap kualitas anak-anak mereka.

Perubahan pola konsumsi (MPC) tidak hanya berkaitan dengan jumlah anak dan selera melainkan juga termasuk harga barang. Kenaikan harga yang terjadi secara umum dan berlaku pada setiap jenis barang disebut inflasi. Inflasi dapat terjadi karena ketidakseimbangan antara jumlah uang $(\mathrm{M})$ yang beredar dengan output barang dan jasa (V) dalam perekonomian. Bila jumlah uang yang beredar (M) melebih dari jumlah output barang/jasa dalam perekonomian maka akan terjadi inflasi, tetapi jika terjadi sebaliknya maka disebut deflasi.

Inflasi yang tinggi (dua digit, disebut hyperinflation) dapat merugikan perekonomian karena beberapa hal: (1) meningkatkan biaya produksi, sehingga mengurangi output yang diproduksi mengakibatkan harga barang makin mahal. (2) mengurangi daya beli masyarakat, sehingga tidak semua barang laku terjual, terjadi over produksi. Keuntungan perusahaan menjadi berkurang bahkan dapat menimbulkan kerugian, sehingga akan terjadi rasionalisasi dalam produksi, menimbulkan pengangguran, dan pada akhirnya dapat menimbulkan kemiskinan penduduk. (3) Inflasi dapat juga menurunkan daya saing barang-barang ekspor jika dibandingkan dengan harga barang dari negara lain. Akibatnya tidak semua barang laku terjual di pasar luar negeri sehingga mengurangi devisa negara, dan neraca perdagangan dapat menjadi defisit, padahal devisa negara menjadi amat penting dalam perdagangan luar negeri (4) inflasi dapat mengurangi tabungan. Makin cepatnya kenaikan harga barang menyebabkan masyarakat tidak tertarik lagi untuk menabung, padahal tabungan merupakan awal untuk terjadinya akumulasi kapital bagi pembangunan. Tetapi apabila inflasinya tidak lebih besar dari satu digit (disebut inflasi moderat) dapat menguntungkan dan merangsang pembangunan, melalui dampaknya pada redistribusi pendapatan dari mereka yang berpendapatan tinggi ke mereka yang berpendapatan rendah (inflasi moderat).

Setidaknya dikenal, dua macam kebijakan untuk mengatasi inflasi, adalah (1) kebijakan fiskal, dan (2) kebijakan moneter. Kebijakan 
fiskal berkaitan dengan politik pengeluaran pemerintah dan perpajakan. Inflasi dapat ditekan melalui pengurangan pengeluaran pemerintah, sehingga dapat menekan harga barang, sedangkan melalui politik perpajakan, dilakukan dengan cara meningkatkan pajak atas perusahaan dan atau pajak perorangan sehingga mengurangi jumlah uang beredar dalam masyarakat, yang pada akhirnya menurunkan harga barang. Sedangkan kebijakan moneter lebih berhubungan dengan politik Bank Sentral, adalah (1) politik cash ratio oleh Bank Sentral, (2) politik discount rate, dan (3) politik pasar terbuka (open market).

Inflasi cenderung mengurangi tabungan masyarakat. Tabungan dapat diartikan sebagai bagian dari pendapatan masyarakat yang tidak dapat dibelanjakan pada saat sekarang melainkan disimpan di lembaga lembaga keuangan bank dan non bank lainnya. Terdapat tiga macam motif untuk menabung: (1) motif transaksi dagang (bisnis), (2) motif berjaga-jaga, dan (3) kepentingan spekulasi.

Motif berjaga-jaga, untuk membiayai keperluan tak terduga, sedangkan motif spekulasi lebih cenderung berhubungan dengan keuntungan (profit), karena itu tergantung kepada tingkat bunga bank. Makin tinggi tingkat bunga (interest $=$ i) bank makin tinggi minat masyarakat untuk menabung, dan sebaliknya, jika bunga bank mengalami penurunan maka akan mengurangi minat masyarakat untuk menabung (Gambar 3).

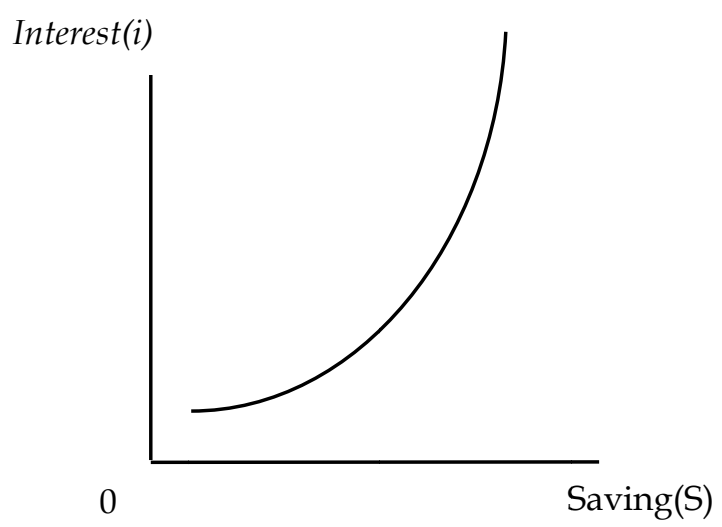

Gambar 3. Hubungan antara Bunga Bank dengan Tabungan
Tabungan cenderung mengurangi kemampuan untuk membeli barang. Akibatnya tidak semua barang laku terjual di pasar, sehingga mengurangi keuntungan bahkan dapat menimbulkan kerugian perusahaan. Padahal berdasarkan keuntungan yang diperoleh perusahaan inilah yang akan membentuk investasi. Investasi secara teoritis berhubungan positif dengan kesempatan kerja, yang dapat mengurangi pengangguran dan kemiskinan. Investasi juga berhubungan positif dengan jumlah barang dan jasa (disebut PDRB) yang diproduksikan dalam perekonomian.

Secara sederhana, PDRB dapat diartikan sebagai penjumlahan barang dan jasa akhir yang dihasilkan oleh sektor pertanian, industri dan sektor jasa. Erfanie (2002), menggunakan data BPS, memaparkan bahwa kontribusi sektor Industri dan Jasa terhadap PDRB perkapita sejak tahun 1993-1998 di atas 60 hingga 73 persen dibanding sektor pertanian. Hal ini sebagai akibat dari rendahnya tingkat pendidikan dan produktivitas tenaga kerja tenaga kerja yang bekerja di sektor pertanian. Berdasarkan harga konstan 2000 PDB Indonesia menurut penggunaan terus mengalami kenaikan dalam enam tahun terakhir (Gambar 4). Nilai PDRB inilah menjadi dasar untuk menilai tingginya tingkat pertumbuhan ekonomi.

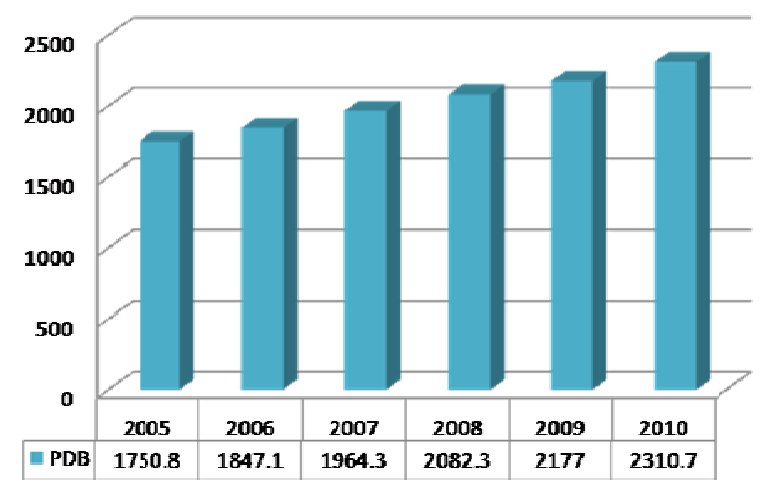

Gambar 4. PDB (triliun Rp) harga Konstan, 2000 menurut Penggunaan (Indonesia)

Neo Klasik beranggapan bahwa pertumbuhan ekonomi hanya disebabkan oleh peranan dari faktor produksi tanah, modal, tenaga kerja, 
dan skill. Tetapi Nafziger (1997) dalam penelitiannya meyakinkan bahwa pertumbuhan ekonomi di Negara-negara Industri baru (New Industry Countries=NICs) seperti Taiwan, Korea Selatan, Hongkong, dan Singapura menunjukan bahwa kontribusi dan K (Kapital) dan L(tenaga kerja) memang dominan antara 50 persen - 90 persen tetapi faktor $\mathrm{T}$ (Teknologi) juga sangat berperan. Tercermin dari nilai sisa yakni nilai $\mathrm{T}$ yang terkandung dalam fungsi produksi Cobb Douglas: $\mathrm{Yt}=\mathrm{Tt} \mathrm{Kt}^{\mathrm{a}} \mathrm{Lt}^{\mathrm{b}}$. Dimana $\mathrm{Yt}$, adalah tingkat produksi (output) pada periode $t$; a dan b menjelaskan produktivitas dari L dan K. Nilai sisa inilah dianggap sebagai pertumbuhan yang disebabkan oleh kemajuan Teknologi (T). Artinya kemajuan $\mathrm{T}$ mampu menyumbang 50 persen dan 10 persen terhadap pertumbuhan ekonomi bagi NICs yang diamati oleh Nafziger (1997).

Melalui proses akselerasi, pertumbuhan ekonomi dapat menciptakan kesempatan kerja, meningkatkan pendapatan perkapita penduduk yang pada akhirnya dapat mengurangi pengangguran dan kemiskinan. Kemiskinan dapat diukur dari dua macam pendekatan, adalah: (1) Kemiskinan absolut, dan (2) Kemiskinan relatif. Pengukuran kemiskinan absolut mengacu kepada sejumlah pendapatan yang cukup untuk memenuhi kebutuhan dasar (basic need) atau kebutuhan primer, adalah makanan, pakaian, dan perumahan. Pendapatan yang dimaksudkan adalah pendapatan minimum yang cukup untuk memenuhi kebutuhan dasar. Batasan pendapatan minimum ini sering disebut sebagai garis kemiskinan. Artinya garis kemiskinan dipergunakan sebagai batas untuk menentukan miskin atau tidaknya seseorang. Penduduk miskin adalah penduduk yang memiliki rata-rata pengeluaran perbulan di bawah garis kemiskinan sebesar Rp211.726 pada tahun 2010 (Berita Resmi BPS Juli 2010). Jumlah penduduk miskin mengalami penurunan dari 32,53 juta (14,2 persen) pada tahun 2009 , menurun menjadi 31,02 juta (13,3 persen) turun 1,51 juta orang, pada tahun 2010.

Kecukupan pendapatan untuk memenuhi kebutuhan dasar tidak serta merta dikatakan seseorang tidak mengalami kemiskinan, apabila masih terdapat keluarga yang memiliki penda- patan jauh melebihi dari pendapatan minimum. Artinya seseorang masih tetap dikatakan miskin apabila di lingkungan tempat tinggalnya terdapat sebagian besar penduduk yang mempunyai pendapatan melebihi dari pendapatan minimum (pendapatan garis batas kemiskinan). Konsep inilah yang dikenal sebagai kemiskinan relatif. Kemiskinan dapat ditilik dari aspek ketimpangan sosial, yang dapat dilihat dari distribusi pendapatan antara kelompok masyarakat yang satu dengan kelompok masyarakat yang lain. Dalam penelitiannya, Dumairy, (1996) menemukan bahwa 20 persen kelompok masyarakat yang berpendapatan tinggi memiliki pendapatan lebih tinggi dari 40 persen kelompok masyarakat yang berpendapatan menengah dan 40 persen yang berpendapatan rendah. Bank Dunia berpendapat bahwa Indonesia termasuk Negara yang memiliki ketimpangan rendah dalam hal distribusi pendapatan. Besarnya pendapatan yang diterima oleh 40 persen penduduk termiskin terus mengalami kenaikan. Pada tahun 1984, 40 persen penduduk termiskin di pedesaan memperoleh 22,35 persen, kemudian meningkat menjadi 25,32 persen di tahun 1997, kecenderungan serupa juga dialami oleh pendudukan di wilayah perkotaan (Tambunan, 2003: 108).

Penelitian yang dilakukan oleh Hasan, dan Quibria pada tahun 2002 menggunakan data panel dari 45 negara di Asia Timur, dan Selatan, Amerika Latin, dan Karibian, serta AfrikaSub-Sahara menemukan bahwa antara pertumbuhan ekonomi dengan kemiskinan mempunyai hubungan negatif, artinya pertumbuhan ekonomi yang tinggi akan mengurangi kemiskinan, dan sebaliknya, rendahnya pertumbuhan ekonomi akan memperbesar angka kemiskinan (Todaro, 2003).

Todaro dan Smith pada tahun 2003 mengatakan bahwa berdasarkan hasil studi empiris di beberapa negara ditemukan bahwa pada awal pertumbuhan ekonomi, distribusi pendapatan cenderung memburuk, namun pada tahap selanjutnya distribusi pendapatan akan membaik seiring dengan makin tingginya pertumbuhan ekonomi. Gambar yang sesuai dengan temuan ini dapat berbentuk huruf $U$ terbalik sebagai berikut (Gambar 5); 


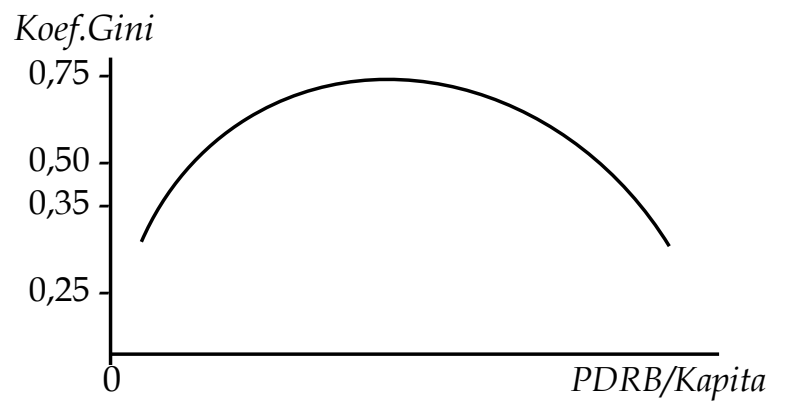

Sumber: Todaro, \& Smith,(2003: 240)

Gambar 5. Hubungan antara Pertumbuhan dengan Distribusi Pendapatan

Argumen tentang teori ini bahwa pada tahap awal, pembangunan memerlukan perubahan-perubahan yang bersifat struktural., sehingga konsentrasi pembangunan, lebih berpusat di sektor industri modern, yang mempunyai lapangan kerja terbatas namun tingkat upah dan produktivitas tinggi. Hipotesis $U$ terbalik dari Kuznets juga berlaku di Indonesia, diamati dari besarnya nilai koefisien gini Indonesia selama tahun 1970-an sampai dengan tahun 1990-an. Pada tahun 1970-an nilai koefisien gini, rendah sebesar 0,31; tahun 1980-an tinggi $(0,36)$, dan pada tahun 1990-an nilai koefisien gini kembali menurun menjadi 0,32. Sementara laju pertumbuhan ekonomi meningkat dalam tiga dekade tersebut (Tambunan, 2003).

Berdasarkan uraian tersebut diketahui bahwa secara teoritis maupun empiris kemiskinan dipengaruhi oleh beberapa variabel baik langsung maupun hubungan tidak langsung. Hubungan langsung artinya variabel sosial yang bersangkutan mempunyai hubungan langsung terhadap kemiskinan tanpa melalui variabel lainnya. Terdapat 5 (lima) macam hubungan langsung yang ingin diketahui adalah: (1) hubungan antara pendidikan, dengan kemiskinan, (2) hubungan antara inflasi, dengan kemiskinan, (3) hubungan antara pendapatan, dengan kemiskinan, (4) hubungan antara PDRB, dengan kemiskinan, dan (5) hubungan antara pertumbuhan ekonomi. Hubungan tidak langsung, artinya variabel sosial yang bersangkutan mempunyai hubungan terhadap kemiskinan melalui variabel sosial lainnya. Bentuk hubungan tidak langsung yang ingin diketahui dalam penelitian ini adalah: (1) hubungan antara pendidikan dengan konsumsi, (2) hubungan antara pendidikan dengan pendapatan, (3) hubungan antara pendidikan dengan PDRB, (4) hubungan antara inflasi dengan konsumsi, (5) hubungan antara pendapatan dengan konsumsi, (6) hubungan antara PDRB dengan pendapatan, (7) hubungan antara pendidikan dengan pertumbuhan ekonomi, (8) hubungan antara inflasi dengan pertumbuhan ekonomi, (9) hubungan antara konsumsi dengan pertumbuhan ekonomi, (10) hubungan antara pendapatan dengan pertumbuhan ekonomi, (11) hubungan antara PDRB dengan pertumbuhan ekonomi

\section{METODE PENELITIAN}

\section{Data dan Variabel}

Penelitian ini menggunakan data (sekunder) panel Indonesia (nasional) berasal dari sumber:

Tabel 2. Variabel dan Sumber Data Penelitian

\begin{tabular}{llcc}
\hline Variabel & \multicolumn{1}{c}{ Pengukuran } & Satuan & Sumber Data \\
\hline Pendidikan Format yang & 1. $\leq$ SD & Orang & BPS \\
ditamatkan (X1) & 2. SMP & & \\
& 3. SLTA & & \\
& 4. Diploma & $\%$ & BPS \\
Inflasi (X2) & 5. Universitas & Jumlah & \\
Konsumsi (X3) & Tingkat Inflasi (y/y) & Jumlah & BPS \\
Pendapatan (X4) & Pengeluaran Masyarakat & Jumlah & BPS \\
PDRB (X5) & Pendapatan/kapita & $\%$ & BPS \\
Pertumbuhan Ekonomi (X6) & PDRB & Tingkat Pertumbuhan & BPS \\
Kemiskinan (Y) & Penduduk yang berada di bawah garis kemiskinan & Jumlah & \\
\hline
\end{tabular}


berita resmi BPS Pusat didukung oleh data terbitan dari Kementerian terkait. Data yang dimaksud berbentuk time series selama 10 tahun terakhir (tahun 1999-2009, berkaitan dengan variabel yang diamati. Variabel dan sumber data yang disajikan dalam Tabel 2.

\section{Metode Analisis Data}

Berdasarkan tujuan yang ingin dicapai maka, alat analisis yang digunakan adalah analisis jalur (Path Analysis). Dimaksudkan untuk melacak hubungan sebab akibat (kausal) antara variabel penelitian dan juga untuk mengetahui jalur hubungan di antara variabel, berdasarkan blok-blok analisis.

Pemodelan. Ada dua macam model yang diajukan adalah:

\section{Model Formal:}

1. Blok 1. X3 = P31X1 +P32X2 + P34X4 + P3q.Q

2. Blok 2. X4 = P41X1 + P45X5 + P4r.R

3. Blok 3. X5 = P51X1 + P5s.S

4. Blok 4. $\mathrm{X} 6=\mathrm{P} 61 \mathrm{X} 1+\mathrm{P} 62 \mathrm{X} 2+\mathrm{P} 63 \mathrm{X} 3+$

$$
\text { P64X4 + P65X5 + P6t.T }
$$

5. Blok 5. $Y=\operatorname{Py} 1 \mathrm{X} 1+\operatorname{Py} 2 \mathrm{X} 2+\mathrm{Py} 4 \mathrm{X} 4+$ Py5X5 + Py6X6 + Pyu.U

\section{Model Informal}

Lihat Gambar 6 tentang Model informal: hubungan kausal antarvariabel.

\section{Matrik Korelasi}

Analisis jalur (path analysis) merupakan pengembangan dari analisis regresi diolah dengan menggunakan software SPSS versi 19. Penggunaan alat ini dimaksudkan untuk mengetahui selain hubungan sebab akibat diantara variabel penelitian juga diketahui hubungan jalur antara satu variabel dengan variabel lainnya sesuai dengan model analisis. Pengolahan data menggunakan dua macam tahapan: (1) penentuan skala data. Data variabel penelitian terlebih dahulu dikelompokkan berdasarkan 2 (dua) macam skala yaitu: (i) skala ordinal, berlaku bagi variabel pendidikan, dan (ii) skala rasio, berlaku bagi variabel inflasi, konsumsi, pendapatan perkapita, PDRB, pertumbuhan ekonomi, dan kemiskinan. (2) penentuan matrik korelasi. Matrik korelasi merupakan data sheet yang digunakan untuk menganalisis hubungan jalur di antara variabel penelitian Matrik korelasi dihasilkan dengan menggunakan alat analisis yang sesuai dengan skala data dimaksud. Analisis rank spearman digunakan untuk menganalisis data yang berskala ordinal, sedangkan regresi untuk menganalisis data yang berskala rasio.

\section{Hipotesis}

Berdasarkan tujuan penelitian tersebut maka hipotesis yang ingin dibuktikan kebenarannya adalah: (1) Terdapat hubungan negatif dan signifikan antara pendidikan dengan kemiskinan, (2) Terdapat hubungan positif dan signifikan

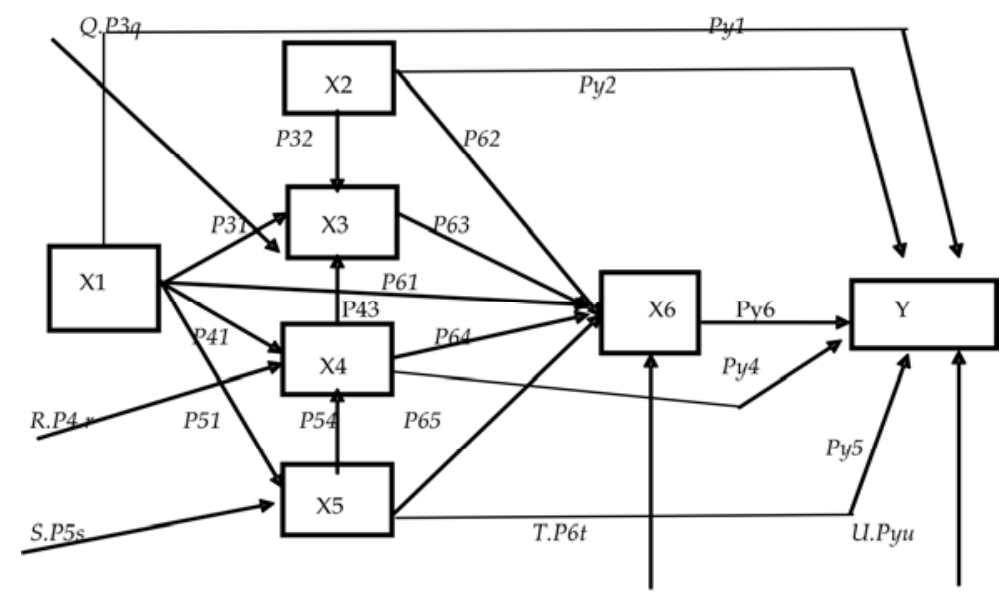

Gambar 6. Model Informal: Hubungan Kausal Antarvariabel 
antara inflasi, dengan kemiskinan, (3) Terdapat hubungan negatif dan signifikan antara pendapatan, dengan kemiskinan, (4) Terdapat hubungan negatif dan signifikan antara PDRB, dengan kemiskinan, (5) Terdapat hubungan negatif dan signifikan antara pertumbuhan ekonomi, dengan kemiskinan, (6) Terdapat hubungan negatif dan signifikan antara pendidikan dengan konsumsi, (7) Terdapat hubungan positif dan signifikan antara pendidikan dengan pendapatan, (8) Terdapat hubungan positif dan signifikan antara pendidikan dengan PDRB, (9) Terdapat hubungan negatif dan signifikan antara inflasi dengan konsumsi, (10) Terdapat hubungan positif dan signifikan antara pendapatan dengan konsumsi, (11) Terdapat hubungan positif dan signifikan antara PDRB dengan pendapatan, (12) Terdapat hubungan positif dan signifikan antara pendidikan dengan pertumbuhan ekonomi, (13) Terdapat hubungan negatif dan signifikan antara inflasi dengan pertumbuhan ekonomi, (14) Terdapat hubungan positif dan signifikan antara konsumsi dengan pertumbuhan ekonomi, (15) Terdapat hubungan positif dan signifikan antara pendapatan dengan pertumbuhan ekonomi, (16) Terdapat hubungan positif dan signifikan antara PDRB dengan pertumbuhan ekonomi.

\section{HASIL DAN PEMBAHASAN}

Rekapan Koefisien Jalur ke Dalam Model Formal sebagai berikut:

1. $\mathrm{X} 3=-0,276 \mathrm{X} 1-0,043 \mathrm{X} 2+0,789 \mathrm{X} 4+0,182 \mathrm{Q}$

2. $\mathrm{X} 4=0,576 \mathrm{X} 1+0,563 \mathrm{X} 5+0,729 \mathrm{R}$

3. $X 5=0,607 X 1+0,794 S$

4. $\mathrm{X} 6=1,161 \mathrm{X} 1-0,835 \mathrm{X} 2+1,512 \mathrm{X} 3+12,217 \mathrm{X} 4$ $+0,249 \times 5+0,786 \mathrm{~T}$

5. $\mathrm{Y}=-0,571 \mathrm{X} 1+0,283 \mathrm{X} 2-0,696 \mathrm{X} 4-0,376 \mathrm{X} 5$ $-0,023 \times 6+0,167 \mathrm{U}$

\section{Penyajian Model Empiris:}

Penyajian hasil analisis kedalam model (empiris) analisis jalur (Gambar 7).

\section{Pembahasan}

Untuk mengetahui hubungan sebab akibat di antara variabel independen (variabel bebas $=X$ ) terhadap variabel dependen (variabel tak bebas $=Y=$ kemiskinan) maka pembahasan hasil penelitiannya mengacu pada model analisis yang ditampilkan mengikuti blok-blok analisis regresi jalur sebagai berikut:

Hubungan antara pendidikan, inflasi, dan pendapatan terhadap konsumsi. Pendidikan

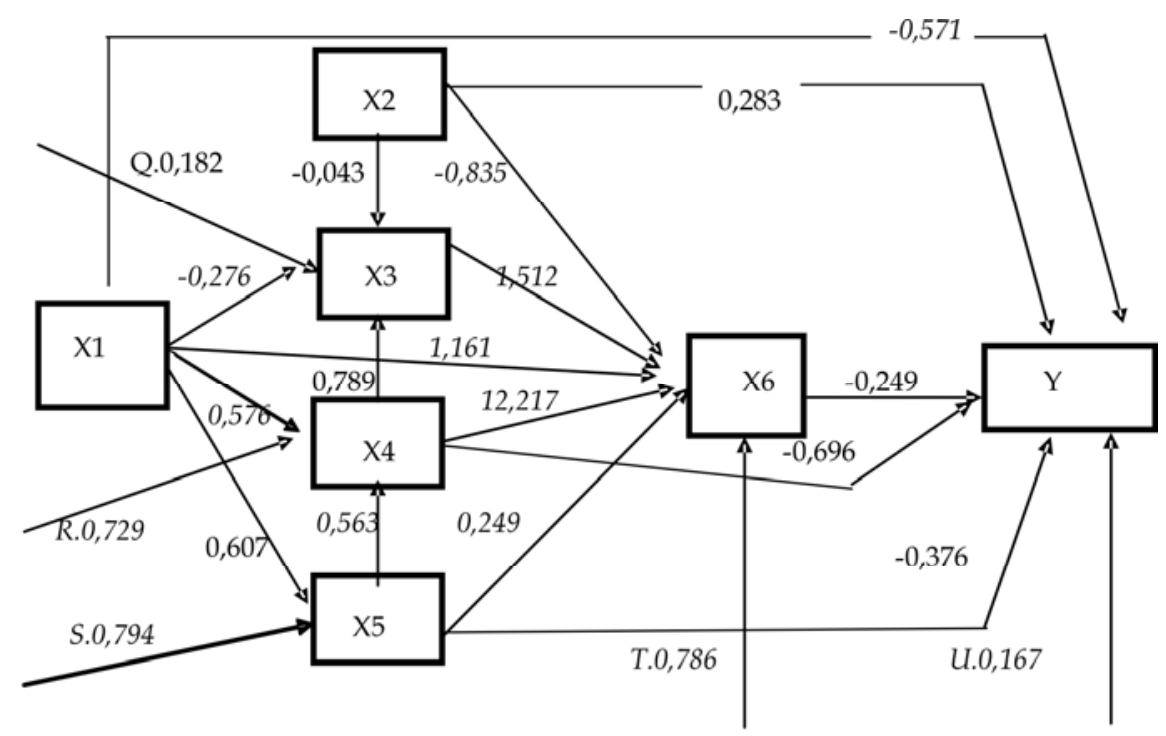

Gambar 7. Model Informal: Hubungan Kausal Antarvariabel 
(formal) merupakan suatu upaya sadar yang dilakukan secara sistematis dan terencana untuk mengembangkan kepribadian dan kemampuan. Djojonegoro pada tahun 1996 mengatakan bahwa pendidikan adalah suatu upaya yang sistematis untuk membentuk manusia yang terampil dan produktif (Bachtiar, 2000). Pendidikan membuat orang menjadi memahami dan menguasai ilmu pengetahuan dan teknologi, yang dapat mempengaruhi perilaku terhadap pola dan kebiasaan konsumsi. Mereka yang berpendidikan tinggi akan lebih selektif melakukan pengeluaran untuk konsumsi.

Hasil penelitian ini menemukan bahwa nilai koefisen regresi (beta terstandart) variabel pendidikan terhadap pengeluaran konsumsi sebesar $-0,275$. Artinya makin tinggi pendidikan makin rendah pengeluaran konsumsi, walaupun di lain pihak terdapat kenaikan pendapatan sebagai akibat dari tingginya pendidikan terakhir yang ditamatkan (H7 terbukti). Pola hubungan ini menjadi signifikan pada taraf signifikansi 0,044 lebih kecil daripada nilai alfa 0,050 (H6 terbukti). Kecenderungan serupa, hubungan negatif juga terjadi antara inflasi dengan konsumsi, dengan koefisien sebesar $-0,043$ dan nilai signifkan 0,005 lebih kecil dari alfa 0,050 (H9 terbukti).Temuan ini memperkuat teori bahwa inflasi cenderung mengurangi pengeluaran konsumsi. Kecuali itu, bahwa pendapatan mempunyai hubungan positif dengan pengeluaran konsumsi, dengan nilai koefisien sebesar 0,789 dan nilai signifikan 0,220 lebih kecil dari alfa 0,050 (H10 terbukti). Ni Lu Sili Antari (2008), dalam penelitian terhadap 80 orang responden pekerja migran dan nonpermanen di Bali (Kabupaten Badung) menemukan bahwa pendapatan mempunyai hubungan positif dengan konsumsi untuk kedua kelompok masyarakat tersebut.

Hubungan positif dan signifikan ini sesuai dengan teori yang disampaikan oleh J.M. Keynes bahwa pendapatan dimanfaatkan untuk kepentingan konsumsi dan tabungan (Mankiw, 2003). Meningkatnya pendapatan dapat memperbesar/memperkecil konsumsi, dan mengurangi/memperbesar tabungan $(Y=C+S)$, di mana $\mathrm{Y}$ adalah pendapatan, $\mathrm{C}$ adalah konsumsi, dan $S$ adalah tabungan.

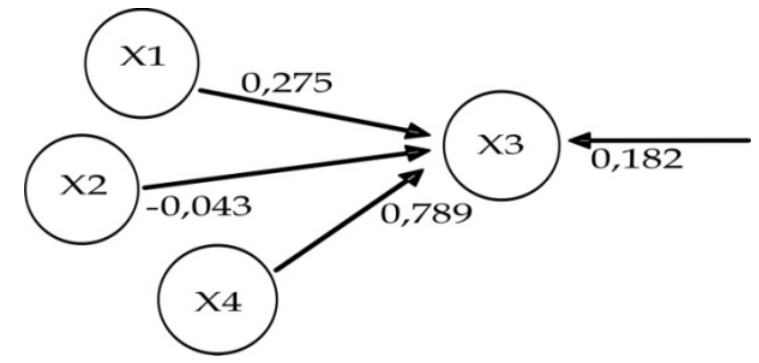

Gambar 8. Hubungan antara variabel pendidikan (X1), inflasi (X2), dan variabel pendapatan (X4) terhadap variabel konsumsi (X3)

Kasus trade off dan atau saling meniadakan terjadi antara $S$ dan C. Bila terjadi kenaikan pendapatan (ceteris paribus), dan $\mathrm{C}$ mengalami kenaikan maka $S$ akan mengalami penurunan, dan sebaliknya jika $S$ yang mengalami kenaikan maka $C$ akan mengalami penurunan. Soal keputusan, apakah $\mathrm{S}$ dan atau $\mathrm{C}$ yang mengalami penurunan tergantung kepada preference dari masing-masing konsumen, karena itu sifatnya relatif.

Perubahan C, tidak hanya karena perubahan pendidikan, pendapatan, inflasi, pola konsumsi (selera) melainkan juga karena kesadaran orang akan makin pentingnya faktor kesehatan. Nicholson pada tahun 2002 mengatakan bahwa hampir semua penelitian membuktikan bahwa orang yang memiliki pendapatan yang lebih tinggi akan menikmati kesehatan yang lebih baik. Hal ini bermula dari kesadaran terhadap pola hidup sehat, yang lebih cenderung dialami oleh orang yang berpendidikan tinggi. Dengan demikian makin tinggi pendidikan tidak hanya berimbas positif kepada kemampuan, produktivitas, dan pendapatan tetapi juga terhadap juga terjadi perubahan pemahaman tentang pola hidup sehat, melalui mengkonsumsi makanan/minuman bergizi, berolahraga, termasuk bertamasya. Ini semua membutuhkan biaya yang tidak sedikit. Dengan demikian maka dapat dikatakan bahwa orang yang berpendidikan tinggi dan berpendapatan tinggi relatif lebih sehat daripada orang yang berpendidikan rendah, dan pendapatan rendah.

Hasil penelitian menunjukkan bahwa pendidikan, inflasi, dan pendapatan secara secara 
bersama-sama mempunyai hubungan yang sangat kuat dan bersifat signifikan dengan konsumsi dengan nilai koefisien regresi (R) sebesar 0.983 , sedangkan besarnya nilai kontribusi $\left(R^{2}\right)$ dari ketiga macam variabel tersebut terhadap besarnya konsumsi sebesar 0,967, mendekati 1.

Hubungan antara Pendidikan dan PDRB, terhadap Pendapatan Perkapita. Hasil penelitian memperlihatkan bahwa pendidikan formal mempunyai hubungan positif dengan pendapatan perkapita penduduk. Nilai koefisiennya sebesar 0,576 dan signifikansi 0,021 (H7 terbukti). Temuan empiris ini menggambarkan bahwa makin tinggi pendidikan makin tinggi kualitas penduduk sehingga orang akan lebih cenderung mencari pekerjaan yang mengandalkan kemampuan otak (brain) daripada otot. Jenis pekerjaan semacam ini akan menghasilkan produktivitas yang tinggi sebagai dasar dalam penentuan upah/gaji. Karena itu tidak mengherankan jika penduduk yang berpendidikan tinggi memiliki pendapatan yang lebih tinggi dari yang berpendidikan rendah. Studi yang dilakukan oleh Psacharopoulos, (1995:10-11) di Venezuela (1989), menemukan bahwa rata-rata pendapatan yang diterima oleh tenaga kerja yang berpendidikan tinggi sebesar 178,297 Bolivares/tahun, lebih tinggi dari yang berpendidikan sekolah menengah: 106,337 Bolivares/ tahun sedangkan untuk yang tamat SD dan tidak tamat SD masing-masing pendapatannya sebesar: 69,452 dan 39,625 Bolivares/tahun. Biro Pusat Statitik Amerika (Bureau of the Census, (1994) menyampaikan bahwa rata-rata penghasilan tenaga kerja di Amerika Serikat untuk yang berpendidikan Doktor mencapai US \$ 54.904.0000/tahun, jauh lebih tinggi dari tenaga kerja yang berpendidikan Magister, atau Sarjana. Rata-rata penghasilan terendah diterima oleh tenaga kerja yang berpendidikan tidak tamat SD sebesar US\$12.809.000/tahun (Suryadi, 1997) (Gambar 9). Besarnya Produk Domestik Regional Bruto (PDRB), tergantung kepada besarnya barang dan jasa yang dihasilkan oleh penduduk. Karena itu penduduk/tenaga kerja yang berkualitas akan menghasilkan PDRB yang lebih tinggi.

Hasil analisis penelitian ini menggambar- kan bahwa nilai koefisien beta berstandar antara pendidikan dengan PDRB sebesar 0,563 dan signifikan 0,029 sehingga hipotesis (H8 terbukti). Melalui mekanisme pasar maka, besarnya PDRB tersebut akan terdistribusi kembali kepada penduduk.

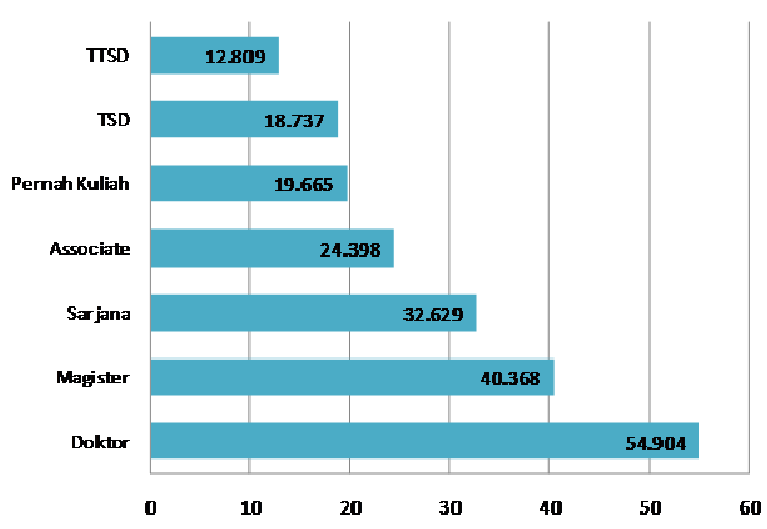

Gambar 9. Rata-rata Penghasilan/tahun di Amerika Menurut Pendidikan Tenaga Kerja (\$000)

Pendidikan dan PDRB secara simultan mempunyai hubungan signifikan dengan pendapatan perkapita, dengan nilai koefisien regresi $(R=0,684)$. Sedangkan kontribusi kedua variabel tersebut terhadap pendapatan perkapita sebesar 47 persen. Pendidikan mempunyai hubungan yang kuat dengan besarnya PDRB. Hasil penelitian menemukan bahwa nilai koefisien regresi sebesar 0,607 dengan nilai $\mathrm{F}$ hitung sebesar 0,048 lebih kecil dari alfa 0,05. (H11 terbukti), sedangkan nilai koefisien determinasinya sebesar 0,368 .

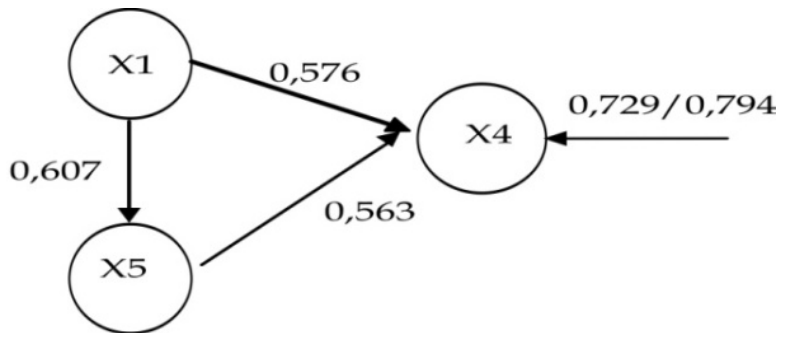

Gambar 10. Hubungan antara Variabel Pendidikan (X1), PDRB (X5), terhadap Variabel Pendapatan (X4) 
Hubungan antara pendidikan, inflasi, konsumsi, pendapatan, dan PDRB terhadap pertumbuhan ekonomi. Berbagai penelitian membuktikan bahwa pendidikan (formal) mempunyai korelasi positif dengan kualitas tenaga kerja dan produktivitas tenaga kerja. Makin tinggi pendidikan makin tinggi kualitas dan produktivitas. Produktivitas diukur dari rasio antara banyaknya output barang dan jasa yang dihasilkan dengan input sumberdaya yang digunakan dalam berproduksi. Denison dalam penelitiannya menemukan bahwa 23 persen dari pertumbuhan output masyarakat Amerika antara tahun 1930-1960 dapat dijelaskan oleh meningkatnya rata-rata tingkat pendidikan tenaga kerja (Suryadi, 1997). Penelitian serupa juga menghasilkan bahwa kontribusi pendidikan terhadap pertumbuhan output masyarakat Amerika antara tahun 1950-1967 sebesar 15 persen. Adam Smith (1776), Heinrich Von Thunen (1875), Schultz (1960), dan Becker (1993) mengatakan bahwa sumberdaya manusia, melalui pendidikan menunjang pertumbuhan ekonomi (economic growth). Selanjutnya dijelaskan bahwa pengeluaran untuk sektor pendidikan harus dipandang sebagai investasi produktif yang sangat bermanfaat bagi pertumbuhan ekonomi. Kontribusi pendidikan terhadap pertumbuhan ekonomi bervariasi untuk tiap-tiap negara seperti nampak dalam Tabel 3.

Penelitian ini memperoleh hasil serupa bahwa pendidikan mempunyai hubungan dengan pertumbuhan ekonomi, dengan nilai koefisien beta terstandart sebesar 1,161. Nilai positif ini menggambarkan bahwa bila pendi- dikan tenaga kerja mengalami peningkatan maka pertumbuhan ekonomi akan bertambah sebesar 1,161. Hubungan ini bersifat signifikan, dengan nilai sebesar 0,015 lebih kecil dari alfa 0,05 , sehingga hipotesis $\mathrm{H}-12$ menjadi terbukti.

Secara teori diketahui bahwa inflasi cenderung mengurangi daya beli masyarakat, sehingga tidak semua barang/output laku terjual di pasar, berarti terdapat over produksi. Keuntungan yang diperoleh perusahaan akan berkurang, bahkan dapat mengalami kerugian. Dalam kondisi ini maka perusahaan perusahaan akan melakukan rasionalisasi, dengan mengurangi output yang diproduksi. Pengurangan output dapat berpengaruh negatif terhadap pertumbuhan ekonomi. Dengan demikian maka inflasi mempunyai hubungan negatif dengan pertumbuhan ekonomi, sama seperti yang ditemukan dalam penelitian ini. Nilai koefisien beta terstandar -0,835 pada taraf signifikan 0,041, sehingga hipotesis (H13) bahwa terdapat hubungan negatif signifikan antara inflasi dengan pertumbuhan ekonomi terbukti diterima. Hipotesis ini bertentangan dengan teori Jean Baptista Say (Todaro, 2003), yang dikenal dengan sebutan Hukum Say, bahwa penawaran (Supply) akan menciptakan permintaannya (Demand) sendiri atau S=D. Teori ini mengandaikan bahwa pendapatan akan dibelanjakan semuanya di pasar, sehingga semua barang yang diproduksikan akan terserap oleh pasar. Kenyataan menunjukkan bahwa pendapatan tidak hanya dimanfaatkan untuk kepentingan konsumsi melainkan juga untuk tabungan (Mankiw, 2003) Y = C + S. Y adalah pendapat-

Tabel 3. Kontribusi Pendidikan Terhadap Pertumbuhan Ekonomi (Perbandingan Antarnegara)

\begin{tabular}{llcllr}
\hline No & Negara & Persentase & No. & Negara & Persentase \\
\hline 1 & Kanada & 25,5 & 11 & Norwegia & 7,0 \\
2 & Amerika Serikat & 15,0 & 12 & Inggris & 12,0 \\
3 & Belgia & 14,0 & 13 & Uni Soviet & 6,7 \\
4 & Denmark & 4,0 & 14 & Korea & 16,5 \\
5 & Perancis & 6,0 & 15 & Jepang & 3,3 \\
6. & Jerman Barat & 2,0 & 16 & Malaysia & 14,7 \\
7 & Greek & 3,0 & 17 & Filipina & 10,5 \\
8 & Israel & 4,7 & 18 & Ghana & 23,2 \\
9 & Itali & 7,0 & 19 & Kenya & 12,4 \\
10 & Belanda & 5,0 & 20 & Nigeria & 16,0 \\
\hline
\end{tabular}

Sumber: Psacharopoulos (1985), dalam Ace Suryadi, 1997 
an, $\mathrm{C}$ adalah konsumsi, dan $\mathrm{S}$ adalah tabungan. Tabungan dapat membentuk akumulasi kapital, yang amat penting bagi pembangunan (Todaro \& Smith, 2003: 92). Tabungan dapat mengurangi kemampuan untuk membeli barang, sehingga akan selalu terjadi di pasar bahwa $S$ tidak akan sama dengan D.

Perteori diketahui bahwa pembentukan PDRB dapat berasal dari pendapatan dan pengeluaran masyarakat. Dalam model perekonomian tertutup, dikenal tiga macam rumah tangga dalam perekonomian adalah: (1) rumah tangga produsen, (2) rumah tangga konsumen, dan (3) rumah tangga pemerintah. Aktivitas dari masing-masing rumah tangga perekonomian tersebut pada akhirnya akan memperoleh balas jasa yang disebut sebagai pendapatan. Besarnya pendapatan ini akan mempengaruhi pengeluaran.

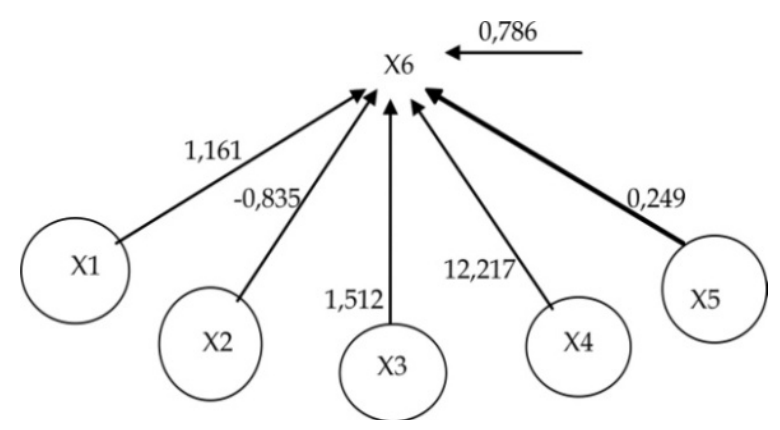

Gambar 11. Hubungan antara variabel pendidikan (X1), inflasi (X2), konsumsi $(X 3)$, pendapatan (X4), PDRB (X5), terhadap variabel pertumbuhan ekonomi (X6)

Pengeluaran yang dilakukan oleh produsen disebut investasi, pengeluaran yang dilakukan oleh konsumen disebut konsumsi, dan pengeluaran yang dilakukan oleh pemerintah dapat dalam bentuk investasi dan atau konsumsi. Pendapatan dan pengeluaran yang diperoleh dan dilakukan oleh ketiga macam rumah tangga tersebut dapat membentuk PDRB, yang pada akhirnya berpengaruh positif terhadap pertumbuhan ekonomi. Penelitian ini membuktikan bahwa pendapatan, pengeluaran dan besarnya PDRB, mempunyai hubungan positif dengan pertumbuhan ekonomi. Nilai koefisien berstandar untuk masing-masingnya terhadap pertumbuhan ekonomi adalah 1,512 untuk konsumsi, 12,217 untuk variabel pendapatan perkapita, dan 0,249 untuk variabel PDRB. Nilai signifikansi untuk ketiga variabel tersebut lebih kecil dari alfa 0,050 sehingga Hipotesis (H14, H15, dan H16) terbukti diterima.

Kesimpulan yang sama juga diperolah ketika diuji serempak yaitu pendidikan, inflasi, konsumsi, pendapatan dan PDRB mempunyai hubungan signifikan dengan pertumbuhan ekonomi. Nilai koefisien regresi $(R=0,618)$ dan besarnya kontribusi variabel pendidikan, inflasi, konsumsi, pendapatan, dan PDRB sebesar 38 persen terhadap pertumbuhan ekonomi (X6). Hubungan simultan ini bersifat signifikan 0,038 lebih kecil dari alfa 0,050.

Hubungan antara pendidikan, inflasi, pendapatan, PDRB, Pertumbuhan ekonomi terhadap kemiskinan penduduk. Perteori diketahui bahwa, pendidikan (formal) meningkatkan kualitas dan produktivitas. Produktivitas diukur dari rasio antara barang dan jasa yang diproduksikan dengan input (tenaga kerja) yang disertakan dalam produksi. Makin banyak output makin produktif. Besarnya output yang diproduksikan oleh masing-masing sektor produktif disebut sebagai produk domestik regional bruto (PDRB). PDRB menjadi dasar dalam perhitungan pertumbuhan ekonomi, yang berhubungan negatif dengan kemiskinan penduduk.

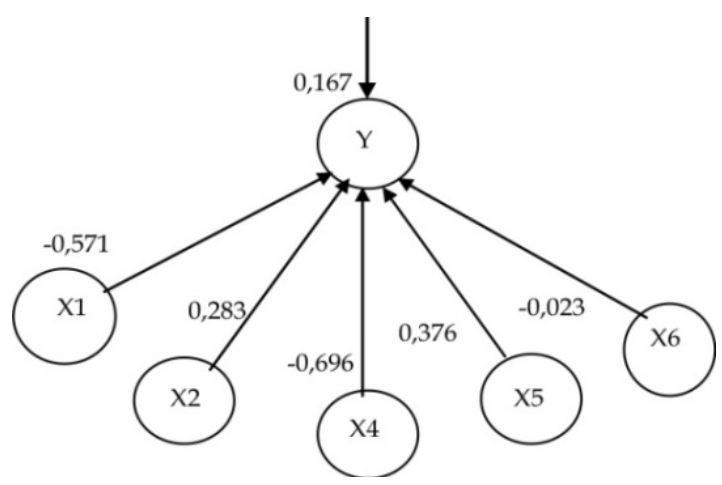

Gambar 12. Hubungan antara variabel pendidikan (X1), inflasi (X2), Pendapatan $(X 4), \operatorname{PDRB}(X 5)$, dan variabel pertumbuhan ekonomi (X6) terhadap kemiskinan penduduk $(\mathrm{Y})$ 
Makin tinggi pertumbuhan ekonomi makin mengurangi angka kemiskinan penduduk. Penelitian ini menemukan bahwa variabel pendidikan, inflasi, pendapatan, PDRB, dan pertumbuhan ekonomi secara simultan berhubungan sangat kuat $(R=0,986)$ dan signifikan dengan kemiskinan.

Kelima variabel ini mempunyai kontribusi terhadap penurunan angka kemiskinan penduduk sebesar 97 persen. Secara parsial, diketahui bahwa masing-masing dari kelima macam variabel tersebut berhubungan dengan kemiskinan penduduk. Pendidikan memiliki hubungan negatif dan signifikan dengan nilai koefisien $-0,571$ terhadap kemiskinan penduduk, sehingga hipotesis $\mathrm{H} 1$ yaitu terdapat hubungan negatif dan signifikan antara pendidikan dengan kemiskinan dinyatakan terbukti diterima.

Inflasi cenderung mengurangi daya beli masyarakat, mengurangi konsumsi dan menimbulkan kelaparan yang pada akhirnya mengakibatkan kemiskinan. Kemiskinan adalah suatu keadaan yang serba kekurangan dialami oleh sebagian penduduk, diukur dari jumlah penduduk yang berada di bawah garis kemiskinan. Batasannya adalah sejumlah pendapatan tertentu yang dihitung berdasarkan tingkat pemenuhan kebutuhan fisik minimum. Jumlah batasan pendapatan ini berbeda tiap Negara bahkan antar wilayah di dalam suatu Negara juga berbeda (Tambunan, 2003). Jika jumlah pendapatan yang diperoleh kurang dari batas pendapatan minimum maka seseorang/kelompok masyarakat tersebut tergolong miskin.

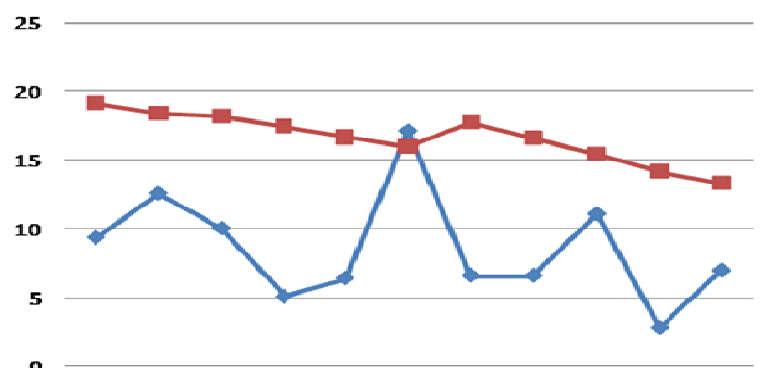

20002001200220032004200520062007200820092010

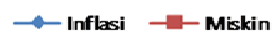

Sumber: Statistik Indonesia, tahun 2000-2010

Gambar 13. Hubungan antara Inflasi dengan Kemiskinan
Inflasi mempunyai hubungan positif dengan kemiskinan, makin tinggi inflasi makin banyak masyarakat miskin. Walaupun demikian berdasarkan data empiris diketahui bahwa hubungannya tidak selalu linear (Gambar 13), tetapi masih positif.

Hal inilah yang mengakibatkan nilai koefisien regresi terstandar hanya sebesar 0,283 tetapi signifikan antara inflasi dengan kemiskian ( $\mathrm{H} 2$ terbukti diterima).

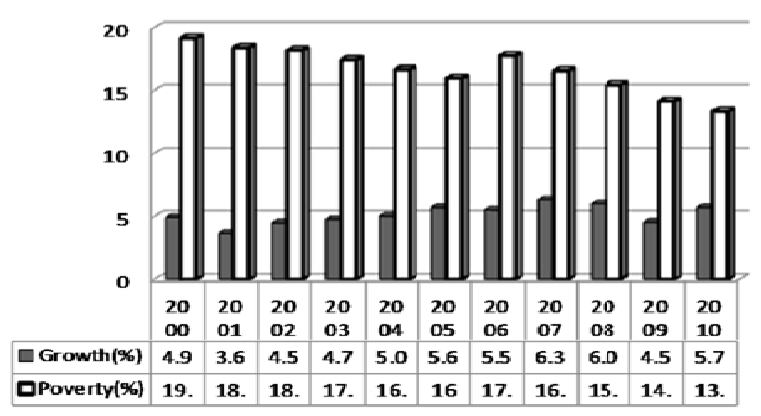

Gambar 14. Hubungan antara Pertumbuhan dengan Kemiskinan

Berbeda dengan inflasi, pendapatan mencerminkan tentang kualitas hidup seseorang. Mereka yang memiliki pendapatan yang lebih tinggi dari batas garis kemiskinan akan mempunyai kemampuan yang lebih untuk memenuhi kebutuhan hidupnya. Dengan demikian maka terjadi trade off antara pendapatan dengan kemiskinan, makin tinggi pendapatan makin mengurangi jumlah penduduk miskin. Tambunan, (2003) menyebutkan bahwa studi yang dilakukan oleh Ravalltion dan Chen, (1997) di 67 negara sedang berkembang menemukan bahwa penurunan kemiskinan hampir selalu dibarengi dengan kenaikan rata-rata pendapatan perkapita atau standar kehidupan. Kecenderungan serupa juga ditemukan dalam penelitian ini bahwa pendapatan mempunyai hubungan negatif dengan faktor kemiskinan, dengan nilai koefisien regresi terstandar sebesar 0,696, dan Signifikan (H3 terbukti, diterima).

Selanjutnya Mills dan Pernia (1993) juga menemukan bahwa kemiskinan di suatu Negara akan semakin rendah jika laju pertumbuhan (PDRB) ekonominya pada tahun-tahun sebe- 
lumnya tinggi (Tambunan, 2003). Wodon pada tahun 1999 menggunakan data panel regional untuk kasus Bangladesh menunjukkan bahwa pertumbuhan ekonomi mengurangi tingkat kemiskinan baik di daerah perkotaan maupun di daerah pedesaan (Tambunan, 2003). Hasil penelitian ini juga memperoleh yang sama, bahwa PDRB mempunyai hubungan negatif dengan kemiskinan. Pertumbuhan ekonomi terbukti mempunyai hubungan negatif dengan kemiskinan dan terbukti signifikan, walaupun hubungannya tidak selalu linear (Gambar 13). Dengan demikin maka hipotesis 4 dan hipotesis 5 terbukti signifikan.

\section{SIMPULAN}

Pendidikan (formal) membuat orang menjadi pintar, dan menguasasi teknologi sehingga meningkatkan produktivitas. Tenaga kerja yang memiliki produktivitas yang tinggi dapat memperoleh pendapatan yang lebih tinggi dari mereka yang rendah produktivitas. Pendapatan berhubungan dengan konsumsi dan kemiskinan. Dikatakan miskin jika jumlah pendapatan yang diperoleh tidak melebihi daripada ketentuan garis batas kemiskinan. Kemiskinan juga dapat dipantau dari tidak cukupnya pendapatan untuk memenuhi kebutuhan konsumsi rumah tangga. Pendapatan dapat digunakan untuk konsumsi, selain tabungan. Makin tinggi pendapatan (ceteris paribus) makin tinggi daya beli masyarakat, dan makin banyak output barang dan jasa yang laku terjual di pasar, sehingga keuntungan pengusaha meningkat. Keuntungan pengusaha dapat menambah investasi, membuka lapangan pekerjaan, berpengaruh terhadap pertumbuhan ekonomi yang pada akhirnya dapat mengurangi pengangguran dan kemiskinan. Hipotesis yang terurai dalam penelitian ini, secara statistik terbukti diterima secara nyata.

\section{DAFTAR PUSTAKA}

Pradeep, Agrawal. 2007. Economic Growth and Poverty Reduction: Evidence from Kazakhstan. http://www.adb.org/documents/ periodicals/adr/pdf/Adr-Vol.242Agrawal.pdf. Diakses tanggal 23 Desember 2011.

Antari, Ni Luh. 2009. Pengaruh Pendapatan, Pendidikan, dan Remitan terhadap Pengeluaran Konsumsi Pekerja Migran Nonpermanen di Kabupaten Badung (Studi Kasus pada Dua Kecamatan di Kabupaten Badung). http://ejurnal.unud. ac.id/new/indeks.p.html. Diakses tanggal 20 Agustus 2011.

Barro, Robert J. 2010. Education and Economic Growth, Harvard University. http://www. oecd.org/dataoecd/5/49/1825455.pdf.

Diakses tanggal 22 Desember 2011.

Berita Resmi Statistik-Badan Pusat Statistik. No.12 /02/Th.XIV, 7 Februari 2011. Pertumbuhan Ekonomi Indonesia. http://dev. sapa.or.id/ download/1/profil kemiskinan. Diakses tanggal 3 Juni 2011.

Bachtiar, Syamsiar. 2000. Hubungan Karakteristik Individu dan Produktivitas Wanita Pekerja di Provinsi Sulawesi Tenggara. Disertasi tidak Terbit. Program Pascasarjana Universitas Negeri Malang.

Black, Hair, Anderson, and Totham. 1998. Multivariate Data Analysis. Fifth Edition. PrenticeHall. International Inc.

Basov, S. 2002. Heterogenous Human Capital: Life Cycle Investment in Health and Education. http://www.economics.unimelb.edu.an. Diakses tanggal 25 Juli 2011.

Becker, G.S. 1993. A Treatise on the Family. Cambridge: Harvard University Press.

Campbell, M.E and Haveman R., et al. 2008. Income Inequality and Racial Gaps in Test Scores. http://www.sanford.duke/pdf. Diakses tanggal 25 Desember 2011.

Durkin Jr., T.T. 2000. Measuring Social Capital and Its Economic Compact. http://www. CAHRS. com/socialcapital.html. Diakses tanggal 12 Desember 2011.

Desi, Dwi dan Bastias. 2010. Analisis Pengaruh Pengeluaran Pemerintah atas Pendidikan, Kesehatan, dan Infrastruktur terhadap Pertum- 
buhan Ekonomi Indonesia Periode 1969- 2009. http://eprints.undip. ac.id/ 22810/ Diakses tanggal 19 Desember 2011.

Eckel Cathering, and Cathleen Johnson. 2003. Human Capital Investment by the Poor: Calibrating Policy with Laboratory Experiments. Departement of Economics Virginia Polytechnic Institute and State University Blacksburg. http://www.VA 24060. 540231-7707. eckelc.edu. Diakses tanggal 21 Desember 2011.

Ehrenberg Ronald. G and Robert S. Smith. 2003. Modern Labor Economics-Theory and Public Policy-Eighth Edition. New York: Electronic Publishing Service Inc..

Fiyya, Setiyaningrum. 2005. Hubungan Tingkat Pendidikan Ibu dan Status Ekonomi Keluarga dengan Pertumbuhan Anak, umur 2-5 tahun di Wilayah Kerja Puskesmas Bangetayu Kecamatan Genuk Kota Semarang. Diakses tanggal 20 Desember 2011.

Gatswacth. 2003. Take Education Out of Gats. http://www.gatswatch.org/ educationoutgats/statement.html. Diakses tanggal 21 Desember 2011

Gylfi, \& Tholfodur Gylfason. 2003. Education, Social Equality and Economic Growth: A view of the Landscape. http://cesifo. Oxfordjour nals.org/content/49/4/557/. Diakses tanggal 20 Desember 2011.

Hanushele, Eric A., et al. 2008. Education and Economic Growth. http://www. education ext.org/educationandeconomicgrowth/. Diakses tanggal 23 Desember 2011.

International Istitute for Applied System Schlossplatz. 2008. Economic Growth in Developing Countries: Education Proves Key. http://www.iiasa.ac.at. Diakses tanggal 23 Desember 2011.

Ismail, Rahma. 1998. Sumbangan Pendidikan Kepada Pertumbuhan Ekonomi Malaysia, 1970-1996 http://journalarticle.ukm.my/ 133. Diakses tanggal 20 Desember 2011.

Jr.H Richard Adams. 2003. Economic Growth, Inequality, and Poverty: Findings from a new
Data Set. http://www.ideasrespec.org/ p/wbk/wbrwps/2927.htm. Diakses tanggal 20 Desember 2011.

Kingdom Geeta Gandhi. 2002. Education of Women and Socio Ecoonomic Development. http:// bahai-Library.com/kingdom_educationa_ Women_ Development. Diakses tanggal 20 Desember 2011.

Helen F, Ladd. 2011. Education and Poverty: Confronting the Evidence. http://sanford. duke. edu/research/papers.pdf/Diakses tanggal 21 Desember 2011.

Mankiw, Gregory N. 2003. Teori Makroekonomi Edisi Kelima (Terjemahan). Jakarta: Erlangga.

Mitch David. 2010. Education and Economi Growth in Historical Prespective. University of Maryland Baltimore Country. http:// www. encyclopedia/article/mitch.educatio. Diakses tanggal 23 Desember 2011.

Mubyarto. 2003. Teori Investasi dan Pertumbuhan Ekonomi dalam Ekonomi Pancasila. Th.II- No.4 Juli, 2003 http:/ / www.ekonomi rakyat.org/ edisi_16/ar. Diakses tanggal 20 Juli 2011.

Nafziger, Wayne E. 1997. The Economics of Developing Countries. Edition third. New Jersey: Prentice-Hall International, Inc.

Nicholson, Walter. 2002. Mikroekonomi Intermediate dan Aplikasinya-Edisi ke delapan (terjemahan). Jakarta: Erlangga.

Norton, W. 2002. Economic Growth and Poverty: Insearch of Trickledown. http://www. questia.com/google. Diakses tanggal 19 Desember 2011.

Nurkolis. 2002. Pendidikan Sebagai Investasi Jangka Panjang. http://re-searchengines.com/ nurkolis5.html. Diakses tanggal 22 September 2011.

Oyekate T.O. 2011. Income Redistribution Growth and Poverty Dynamic during the Period of Economic Reform Nigeria. http://www. inpindia.In/411/. Diakses tanggal 20 Desember 2011.

Panu Poutvaara. 2005. Social Security Inventives, Human Capital Investment and Mobility of 
Labor. Centre for Economic and Business Research, Cesifo and IZA. 20 January 2005.

Psacharapoulos, G. 1993. The Profitability of Investment in Education: Concept and methods. http://www.Socserv2.SocSci.Mcmaster. ca/. Diakses, tanggal 19 Agustus 2011.

Profil Kemiskinan di Indonesia Maret 2009. http:/ /tnp2k.wapresri.go.id/data/profilkemiskinan-indonesia.html. Diakses tanggal 7 Juni 2011.

Ranis, Gustav. 2004. Human Development and Economi Growth. Yale University. http:// www.econ.yale.edu/growth_pdf/Diakses tanggal 21 Desember 2011.

Robins, Stephen P. 1990. Organizational Behavior Concepts. Controversies and Application (Four edition). India New Delhi: Prentice Hall.

Schultz, T.W. 1981. Investing in People: The Economic of Population Quality. Amerika Serikat: University of California Press.

Sjamtjik, M.L. 2003. Pengaruh Pendidikan terhadap Penghasilan Tenaga Kerja di Kota Palembang. Kajian Ekonomi-Jurnal Penelitian Bidang Ekonomi. Vol.2 Nomor 1. Palembang. Program Studi Ilmu Ekonomi-Pascasarjana Universitas Sriwijaya.

Solow, Roberth M..2003. Poverty and Economic Growth. http://www.irp.wis.edu/publica tion/focus/pdf. Diakses tanggal 20 Desember 2011.

Stamatakis, D \& P.E. Petrakis. 2001. Growth and Educational Levels: a Comparative Analysis. http://www.scribd.com/doc/60782262/. Diakses tanggal 20 Desember 2011.

Suryadi, A. 1997. Pendidikan,Investasi SDM dan Pembangunan. Jakarta: Pusat Informatika Balitbang DIKBUD .

Suharsaputra, Uhar. 2003. Nilai Ekonomi dari Pendidikan. http://uharsaputra.wordpress. com/pendidikan/ekonomi-pendidikan/.

Diakses tanggal 8 September 2011.

Tambunan, T.T.H. 2003. Perekonomian Indonesia Beberapa Masalah Penting. Jakarta: Ghalia Indonesia.

Tambunan T.T.H. 2004. Pertumbuhan Ekonomi dan Pengurangan Kemiskinan: Kasus Indonesia. Jurnal: Kajian Ekonomi Vol.3 No. 2. Palembang. Program Studi Ilmu Ekonomi Program Pascarjana Universitas Sriwijaya.

Todaro, M. P. 2000. Pembangunan Ekonomi di Dunia Ketiga (terjemahan). Jakarta: Erlangga.

Woesman Ludger and Jamison, et al. 2011. Education and Economic Growth. http:// education-ext.org/education and Econo mic Growth. Diakses tanggal 20 September 2011.

Soto Marcelo and Daniel Cohon. 2007. Economic Growth and Human Capital: Good Data, Good Results. Volume 12 Issue 1. http:// ideas. repec.org/s/kap/Jecgro.htm. Diakses tanggal 20 September 2011.

Jaypee Sevila and David, et al. 2003. Geography and Poverty Trap. Volume 8 Issue 4. http:// ideas.repec.org/s/Kap/jecgro.htm. Diakses tanggal 20 September 2011.

Gugerty Kay Mary and Michael Roemer. 1997. Does Economic Growth Reduce Poverty? http://pdf.usaid.gou/pdf_.docs/PNACA6 56. pdf. Diakses tanggal 20 September 2011.

Jongwanich Juthatpit. 2007. Workers Remittance Economic Growth and Poverty in Developing Asia and the Pacific Countries. http:// www. unescap.org/pdd/publications/workingpa per/wp0701/pdf. Diakses tanggal 20 September 2011.

Weale Martin and Philip Stevens. 2003. Education and Economic Growth. National Institute of Economic and and Social Reaech, 2, Dean Trenc Stree, London SWIP 3HE. Diakses tanggal 20 September 2011. 